\title{
Jurassic silicic volcanism in the Transantarctic Mountains: Was it related to plate margin processes or to Ferrar magmatism?
}

\author{
D. H. Elliot, ${ }^{1}$ T. H. Fleming, ${ }^{2}$ K. A. Foland, ${ }^{3}$ and C. M. Fanning ${ }^{4}$ \\ ${ }^{1}$ Byrd Polar Research Center and Department of Geological Sciences, The Ohio State University, Columbus, OH 43210, USA \\ ${ }^{2}$ Department of Earth Sciences, Southern Connecticut State University, New Haven, CT 06515, USA \\ ${ }^{3}$ Department of Geological Sciences, The Ohio State University, Columbus, OH 43210, USA \\ ${ }^{4}$ Research School of Earth Sciences, Australian National University, Canberra, ACT 2000, Australia
}

\begin{abstract}
Silicic volcanism in the Transantarctic Mountains, represented by rhyolitic tuff that mainly precedes emplacement of the Ferrar Large Igneous Province, is important in interpretation of the tectonic evolution of the Antarctic sector of Gondwana. Sr and Nd isotope data indicate that the tuffs are not directly related to Ferrar magmatism nor to melting of the underlying Ross orogen crust yet zircon gives a U-Pb age of $182.7 \pm 1.8 \mathrm{Ma}$, similar to the $\mathrm{U} / \mathrm{Pb}$ age for the Ferrar. Distribution of the silicic tuffs along $1400 \mathrm{~km}$ of the Transantarctic Mountains suggests, alternatively, a relationship to the Gondwana plate margin. Although West Antarctica comprises Mesoproterozoic crustal terrains, few analyzed rocks are compatible isotopically with the Lower Jurassic tuffs. The source of the tuffs must lie in unexposed Early Jurassic magmatic centers in West Antarctica or an unexposed crustal terrain beneath the Transantarctic Mountains.
\end{abstract}

Citation: Elliot, D.H., T.H. Fleming, K.A. Foland, and C.M. Fanning (2007), Jurassic silicic volcanism in the Transantarctic Mountains: was it related to plate margin processes or to Ferrar magmatism: in Antarctica: A Keystone in a Changing World - Online Proceedings of the 10th ISAES, edited by A.K. Cooper and C.R. Raymond et al., USGS Open-File Report 2007-1047, Short Research Paper 051, 5 p.; doi:10.3133/of2007-1047.srp051

\section{Introduction}

Silicic magmatism was an integral part of some large igneous provinces, such as the Parana-Etendeka (e.g. Peate, 1997). In that and other instances silicic extrusive rocks of anatectic origin are interbedded with voluminous tholeiitic lavas. In the Transantarctic Mountains (TAM) (Fig. 1; Elliot, 2000) silicic shards and volcaniclastic debris occur in stratigraphic sequences (Hanson Fm) underlying Lower Jurassic Ferrar extrusive rocks, as clasts enclosed in the basaltic pyroclastic rocks that underlie the lavas, and as sparsely distributed shards in interbeds within the lava sequence. This paper presents stratigraphic, isotopic and chronologic data on the silicic rocks, and evaluates the relationship of the silicic magmatism to the Ferrar Large Igneous Province and other possible sources.

\section{Stratigraphy}

The only continuous stratigraphic sequences extending from the Upper Triassic strata of the Victoria Group to the Lower Jurassic Ferrar extrusive rocks are exposed in the central Transantarctic Mountains (CTM) (Elliot, 2000 and references therein) and at Shafer peak, Deep Freeze Range, north Victoria Land (NVL) (Schoener et al., this symposium). The Hanson Fm type section, at Mt. Falla (CTM), is a 238-m-thick sequence of volcaniclastic sandstones and siltstones together with tuffaceous beds, which is divided into three informal members, with tuffs and reworked tuffs dominant in the upper member. Hanson strata are thinner elsewhere and the members are less readily recognized, although the upper member everywhere is dominated by tuffs. The overlying basaltic pyroclastic Prebble Fm, $\leq 204 \mathrm{~m}$ thick, includes occasional clasts of silicic tuff, which at Otway Massif are up to $10 \mathrm{~m}$ across. The overlying Kirkpatrick Basalt, $\approx 550 \mathrm{~m}$ thick, comprises numerous

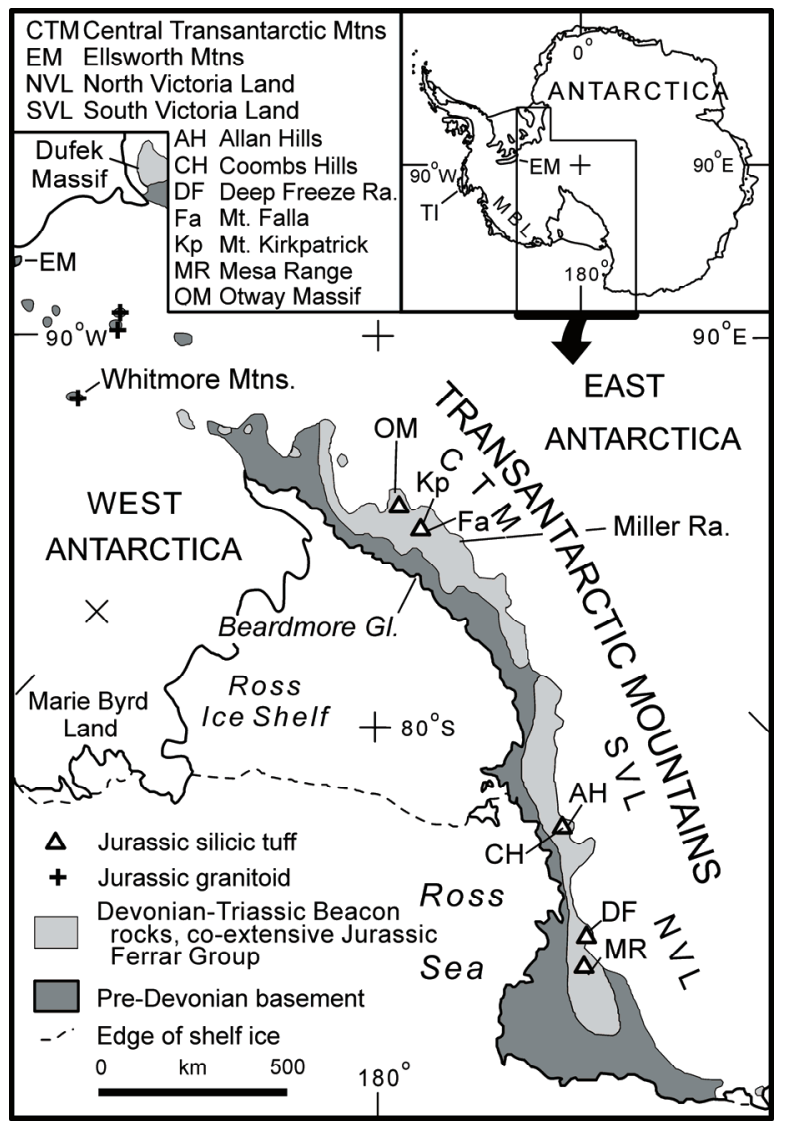

Figure 1. Location map for Lower Jurassic silicic volcanic rocks in the Transantarctic Mountains.

lava flows with interbeds near the top and bottom of the sequence. Changes in stratigraphic thickness of the Hanson Fm suggest it is disconformity bound.

In south Victoria Land (SVL), at Coombs Hills, the Upper Triassic Lashly Fm is overlain by a silicic shard- 
bearing clastic unit (Fig. 2); however, there is no unequivocal stratigraphic contact with younger rocks (Elliot et al., 2006). Silicic tuff megaclasts have been reported from Allan Hills but none has been found in situ in the basaltic pyroclastic Mawson Fm. Near Mt. Weir, Deep Freeze Range (NVL), silicic tuff occurs in the basaltic pyroclastic Exposure Hill Fm (Elliot, unpublished data). At nearby Mt. Shafer siliciclastic shard-bearing sandstones occur within the Exposure Hill Fm; a black shale in this sequence has an Early Jurassic palynological age (Musumeci et al., 2006). In the Mesa Range region (NVL), sandstones with silicic shards overlie the Lower Jurassic Section Peak Fm (Pertusati et al., 2006). The Exposure Hill Fm includes silicic shards and tuff megaclasts. The detailed relationships between the Jurassic units in the Mesa Range region (NVL) are discussed by Schoener et al. (this symposium).

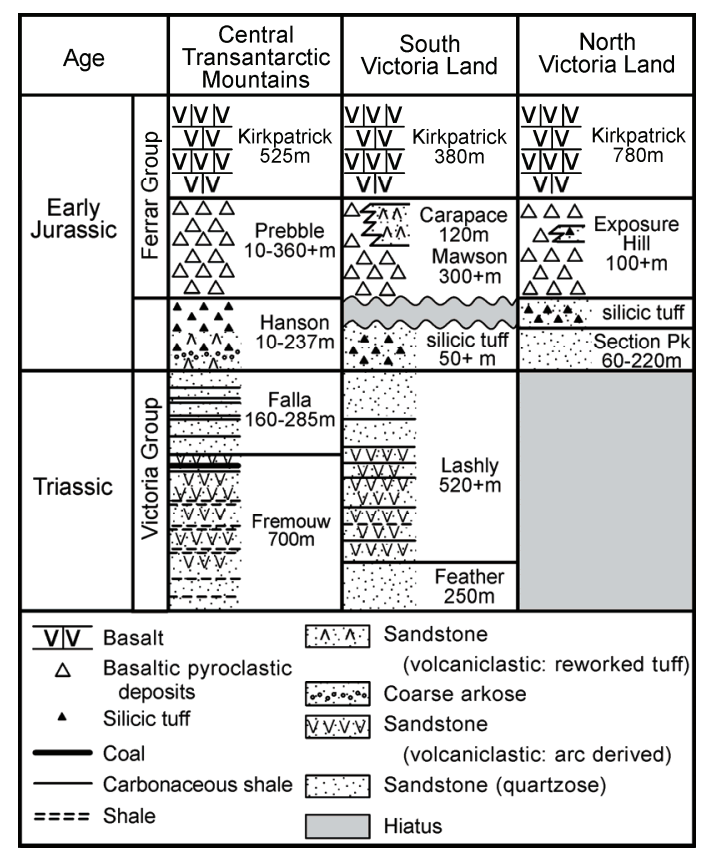

Figure 2. Stratigraphic columns for Triassic and Jurassic strata in the Transantarctic Mountains.

\section{Age}

The age of the Hanson Fm is not well constrained. It overlies the upper Triassic (Carnian to Norian) Falla Fm (see Elliot, 2000) and is older than the overlying Ferrar rocks. Four tuffaceous samples from the upper Hanson Fm at Mt. Falla gave an Rb-Sr "isochron" age of $186 \pm 8$ Ma (Faure and Hill, 1973). The dinosaur from the Hanson Fm has been assigned a SinemurianPliensbachian (Early Jurassic) age (Hammer and Hickerson, 1994). Based on U-Pb zircon and baddeleyite analyses, the Ferrar has an age of $183.6 \pm 1.8$ Ma (Encarnación et al., 1996), which is close to the Pleinsbachian-Toarcian stage boundary.

A silicic tuff clast from Otway Massif yielded an anomalously young whole rock ${ }^{40} \mathrm{Ar} /{ }^{39} \mathrm{Ar}$ age of $\approx 160$
Ma (Middle Jurassic), which is attributed to Ar loss by low temperature processes. Zircon, from the same tuff clast, has given a U-Pb SHRIMP age of $182.7 \pm 1.8 \mathrm{Ma}$ (Fig. 3; Table 1).

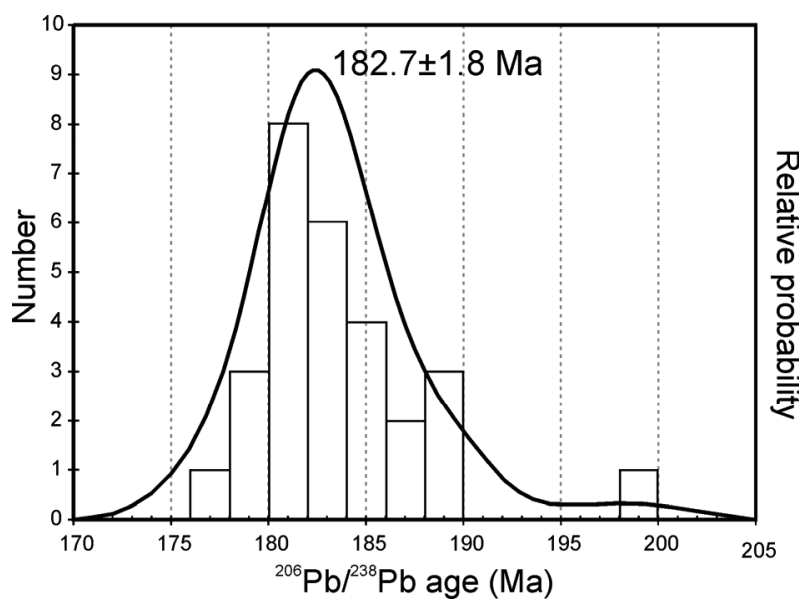

Figure 3. U-Pb zircon age probability plot for a silicic tuff clast from Otway Massif. Analysis performed at the Australian National University, under standard operating and data reduction procedures.

\section{Chemistry}

The Hanson Fm silicic rocks are dacite to high-silica rhyolite $\left(\mathrm{SiO}_{2}=67-78 \%\right)$ in composition (see Elliot, 2000; unpublished data). The major elements show considerable scatter, which is attributed, in part, to admixed detrital material (rock fragments and mineral grains) and to alteration (clay minerals and zeolites). High field strength elements show the least scatter, and on chondrite-normalized incompatible element diagrams show Nb-Sr-P-Ti depletions typical of rocks with a strong crustal influence. A crustal signature is also suggested by ${ }^{87} \mathrm{Sr} /{ }^{86} \mathrm{Sr}$ isotope initial ratios of 0.7091 0.7102 and ${ }^{143} \mathrm{Nd} /{ }^{144} \mathrm{Nd}$ initial ratios of $0.51220-0.51226$ $\left(\epsilon_{\mathrm{Nd}}\right.$ values of -2.8 to -4.0 at $\left.183 \mathrm{Ma}\right)$ for three in situ Hanson tuffs and two tuff clasts from the Prebble Fm (Fig. 4; Table 2).

\section{Discussion}

The zircon U-Pb SHRIMP age of $182.7 \pm 1.8 \mathrm{Ma}$ for the silicic tuff clast enclosed in basaltic tuff breccia is similar to the $\mathrm{U}-\mathrm{Pb}$ age (by thermal ionization mass spectrometry) assigned to the Ferrar rocks, and therefore temporal association with the Ferrar province is indicated.

The $\mathrm{Sr}$ isotope data for the tuffs (Table 2) indicate a crustal influence in their genesis. The $\mathrm{Sr}$ isotope initial ratios are significantly lower than most of the underlying upper crustal rocks of the Lower Paleozoic Ross Orogen, which are generally $>0.720$ at $183 \mathrm{Ma}$ (Borg et al., 1990); this suggests the tuffs were not derived by anatexis of such crust. However the silicic tuff $\mathrm{Sr}$ isoptope initial ratios are within the range of lower crustal xenoliths from SVL (Kalamarides et al., 
Table 1. Summary of SHRIMP U-Pb zircon results for sample 96-27-14.

\begin{tabular}{|c|c|c|c|c|c|c|c|c|c|c|c|c|c|c|}
\hline \multirow[b]{2}{*}{$\begin{array}{c}\text { Grain. } \\
\text { spot }\end{array}$} & \multirow[b]{2}{*}{$\begin{array}{c}\mathrm{U} \\
(\mathrm{ppm})\end{array}$} & \multirow[b]{2}{*}{$\begin{array}{c}\text { Th } \\
(\mathrm{ppm})\end{array}$} & \multirow[b]{2}{*}{$\mathrm{Th} / \mathrm{U}$} & \multirow[b]{2}{*}{$\begin{array}{r}{ }^{206} \mathrm{~Pb}^{*} \\
(\mathrm{ppm})\end{array}$} & \multirow[b]{2}{*}{$\begin{array}{l}{ }^{204} \mathrm{~Pb} / \\
{ }^{206} \mathrm{~Pb}\end{array}$} & \multirow[b]{2}{*}{$\begin{array}{c}\mathrm{f}_{206} \\
\%\end{array}$} & \multicolumn{4}{|c|}{ Total } & \multicolumn{2}{|c|}{ Radiogenic } & \multicolumn{2}{|c|}{ Age (Ma) } \\
\hline & & & & & & & $\begin{array}{l}{ }^{238} \mathrm{U} / \\
{ }^{206} \mathrm{~Pb}\end{array}$ & \pm & $\begin{array}{l}{ }^{207} \mathrm{~Pb} / \\
{ }^{206} \mathrm{~Pb}\end{array}$ & \pm & $\begin{array}{l}{ }^{206} \mathrm{~Pb} / \\
{ }^{238} \mathrm{U}\end{array}$ & \pm & $\begin{array}{l}{ }^{206} \mathrm{~Pb} / \\
{ }^{238} \mathrm{U}\end{array}$ & \pm \\
\hline \multicolumn{15}{|l|}{$\underline{\mathrm{Z} 4420}$} \\
\hline$\overline{1} .1$ & 199 & 359 & 1.80 & 5.1 & 0.000263 & $<0.01$ & 33.57 & 0.43 & 0.0493 & 0.0011 & 0.0298 & 0.0004 & 189.4 & 2.4 \\
\hline 2.1 & 256 & 336 & 1.32 & 6.4 & 0.000431 & 1.13 & 34.12 & 0.42 & 0.0588 & 0.0015 & 0.0290 & 0.0004 & 184.2 & 2.3 \\
\hline 3.1 & 356 & 425 & 1.19 & 8.9 & 0.000009 & 0.19 & 34.34 & 0.41 & 0.0513 & 0.0009 & 0.0291 & 0.0004 & 184.7 & 2.2 \\
\hline 4.1 & 594 & 595 & 1.00 & 14.9 & 0.000100 & 0.14 & 34.33 & 0.38 & 0.0509 & 0.0007 & 0.0291 & 0.0003 & 184.9 & 2.0 \\
\hline 5.1 & 366 & 293 & 0.80 & 9.1 & 0.000103 & $<0.01$ & 34.61 & 0.40 & 0.0495 & 0.0009 & 0.0289 & 0.0003 & 183.7 & 2.1 \\
\hline 6.1 & 1194 & 1115 & 0.93 & 30.3 & 0.001436 & 2.39 & 33.90 & 0.36 & 0.0688 & 0.0011 & 0.0288 & 0.0003 & 183.0 & 2.0 \\
\hline 7.1 & 2143 & 1012 & 0.47 & 54.2 & 0.000230 & 0.39 & 34.00 & 0.35 & 0.0529 & 0.0004 & 0.0293 & 0.0003 & 186.2 & 1.9 \\
\hline 8.1 & 106 & 47 & 0.45 & 18.1 & 0.000121 & 0.30 & 5.02 & 0.06 & 0.0814 & 0.0008 & 0.1988 & 0.0026 & 1168.9 & 14.1 \\
\hline 9.1 & 108 & 121 & 1.12 & 2.7 & 0.000715 & 0.42 & 34.84 & 0.52 & 0.0530 & 0.0017 & 0.0286 & 0.0004 & 181.7 & 2.7 \\
\hline 10.1 & 292 & 366 & 1.25 & 7.2 & 0.000593 & 0.77 & 34.82 & 0.42 & 0.0559 & 0.0010 & 0.0285 & 0.0003 & 181.1 & 2.2 \\
\hline 11.1 & 442 & 364 & 0.82 & 10.8 & 0.000267 & 0.10 & 35.03 & 0.40 & 0.0505 & 0.0008 & 0.0285 & 0.0003 & 181.3 & 2.1 \\
\hline 12.1 & 181 & 290 & 1.60 & 4.4 & 0.000179 & 0.63 & 35.11 & 0.46 & 0.0547 & 0.0013 & 0.0283 & 0.0004 & 179.9 & 2.4 \\
\hline \multicolumn{15}{|l|}{$\underline{\mathbf{Z} 4974}$} \\
\hline 1.1 & 266 & 286 & 1.07 & 7.2 & - & 0.36 & 31.92 & 0.59 & 0.0530 & 0.0011 & 0.0312 & 0.0006 & 198.1 & 3.6 \\
\hline 2.1 & 100 & 138 & 1.39 & 2.4 & - & 0.55 & 35.01 & 0.53 & 0.0541 & 0.0018 & 0.0284 & 0.0004 & 180.6 & 2.7 \\
\hline 3.1 & 56 & 56 & 1.01 & 1.4 & 0.000018 & 0.23 & 34.96 & 0.64 & 0.0515 & 0.0024 & 0.0285 & 0.0005 & 181.4 & 3.3 \\
\hline 4.1 & 99 & 163 & 1.65 & 2.4 & - & 0.16 & 34.82 & 0.53 & 0.0510 & 0.0017 & 0.0287 & 0.0004 & 182.2 & 2.8 \\
\hline 5.1 & 2647 & 3639 & 1.37 & 65.8 & 0.000051 & $<0.01$ & 34.55 & 0.36 & 0.0494 & 0.0003 & 0.0290 & 0.0003 & 184.0 & 1.9 \\
\hline 6.1 & 1638 & 1681 & 1.03 & 41.1 & 0.001246 & 2.13 & 34.25 & 0.36 & 0.0667 & 0.0006 & 0.0286 & 0.0003 & 181.6 & 1.9 \\
\hline 7.1 & 276 & 388 & 1.40 & 7.5 & 0.007145 & 12.55 & 31.61 & 0.54 & 0.1497 & 0.0060 & 0.0277 & 0.0005 & 175.9 & 3.4 \\
\hline 8.1 & 271 & 266 & 0.98 & 6.7 & 0.000005 & 0.20 & 34.97 & 0.43 & 0.0513 & 0.0011 & 0.0285 & 0.0004 & 181.4 & 2.2 \\
\hline 9.1 & 548 & 519 & 0.95 & 13.3 & - & 0.05 & 35.32 & 0.40 & 0.0501 & 0.0007 & 0.0283 & 0.0003 & 179.9 & 2.0 \\
\hline 10.1 & 359 & 108 & 0.30 & 51.9 & - & 0.10 & 5.93 & 0.06 & 0.0734 & 0.0005 & 0.1684 & 0.0019 & 1003.0 & 10.4 \\
\hline 11.1 & 1876 & 2472 & 1.32 & 48.1 & 0.000020 & $<0.01$ & 33.54 & 0.35 & 0.0494 & 0.0004 & 0.0298 & 0.0003 & 189.5 & 2.0 \\
\hline 12.1 & 108 & 144 & 1.33 & 2.7 & 0.000923 & 0.05 & 33.68 & 0.51 & 0.0503 & 0.0017 & 0.0297 & 0.0005 & 188.5 & 2.8 \\
\hline 13.1 & 310 & 107 & 0.35 & 34.5 & 0.000133 & 0.17 & 7.73 & 0.09 & 0.0667 & 0.0006 & 0.1292 & 0.0015 & 783.4 & 8.4 \\
\hline 14.1 & 468 & 403 & 0.86 & 11.5 & 0.000392 & 0.05 & 34.85 & 0.40 & 0.0501 & 0.0008 & 0.0287 & 0.0003 & 182.3 & 2.1 \\
\hline 15.1 & 3489 & 5246 & 1.50 & 90.4 & 0.001417 & 2.57 & 33.17 & 0.34 & 0.0703 & 0.0018 & 0.0294 & 0.0003 & 186.6 & 1.9 \\
\hline 16.1 & 2220 & 3288 & 1.48 & 55.1 & 0.000041 & 0.11 & 34.63 & 0.37 & 0.0506 & 0.0004 & 0.0288 & 0.0003 & 183.3 & 1.9 \\
\hline 17.1 & 210 & 321 & 1.53 & 5.2 & 0.000072 & 0.48 & 34.74 & 0.46 & 0.0535 & 0.0015 & 0.0286 & 0.0004 & 182.1 & 2.4 \\
\hline 18.1 & 197 & 334 & 1.69 & 4.7 & 0.000245 & 0.18 & 36.01 & 0.47 & 0.0511 & 0.0013 & 0.0277 & 0.0004 & 176.3 & 2.3 \\
\hline 19.1 & 184 & 195 & 1.06 & 4.4 & 0.000354 & 0.22 & 35.59 & 0.48 & 0.0514 & 0.0014 & 0.0280 & 0.0004 & 178.2 & 2.4 \\
\hline 20.1 & 1194 & 791 & 0.66 & 29.5 & 0.000319 & 0.51 & 34.81 & 0.37 & 0.0538 & 0.0006 & 0.0286 & 0.0003 & 181.6 & 1.9 \\
\hline
\end{tabular}

Notes: 1. Uncertainties given at the one sigma level.

2. Error in Temora reference zircon calibration was $0.65 \% \& 0.58 \%$ for the analytical sessions.

( not included in above errors but required when comparing data from different mounts).

3. $\mathrm{f}_{206} \%$ denotes the percentage of ${ }^{206} \mathrm{~Pb}$ that is common $\mathrm{Pb}$.

4. Correction for common $\mathrm{Pb}$ made using the measured ${ }^{238} \mathrm{U} /{ }^{206} \mathrm{~Pb}$ and ${ }^{207} \mathrm{~Pb} /{ }^{206} \mathrm{~Pb}$ ratios following Tera and Wasserburg (1972) as outlined in Williams (1998).

Table 2. $\mathrm{Rb}, \mathrm{Sr}, \mathrm{Sm}$, and $\mathrm{Nd}$ concentrations and ${ }^{87} \mathrm{Sr} /{ }^{86} \mathrm{Sr}$ and ${ }^{143} \mathrm{Nd} /{ }^{144} \mathrm{Nd}$ present day and calculated initial ratios at 183 Ma for silicic tuffs. Samples (all have prefix 85-) 1 (3-24A) and 2 (11-10): Prebble Formation tuff clasts. Samples 3 (16-24), 4 (19-2), and 5 (20-11): Hanson Formation tuffs. Methods are given in Foland and Allen (1991).

\begin{tabular}{|c|c|c|c|c|c|c|c|c|c|c|c|c|}
\hline \# & $\begin{array}{c}\mathrm{Rb} \\
(\mathrm{ppm})\end{array}$ & $\begin{array}{c}\mathrm{Sr} \\
(\mathrm{ppm})\end{array}$ & ${ }^{87} \mathrm{Rb} /{ }^{86} \mathrm{Sr}$ & ${ }^{87} \mathrm{Sr} /{ }^{86} \mathrm{Sr}$ & $\left({ }^{87} \mathrm{Sr} /{ }^{86} \mathrm{Sr}\right)_{\mathrm{i}}$ & $\begin{array}{l}\mathrm{Sm} \\
(\mathrm{ppm})\end{array}$ & $\begin{array}{c}\mathrm{Nd} \\
(\mathrm{ppm})\end{array}$ & $\begin{array}{l}{ }^{147} \mathrm{Sm} / \\
{ }^{144} \mathrm{Nd}\end{array}$ & ${ }^{143} \mathrm{Nd} /{ }^{144} \mathrm{Nd}$ & $\left({ }^{143} \mathrm{Nd} /{ }^{144} \mathrm{Nd}\right)_{\mathrm{i}}$ & $\mathrm{E}_{\mathrm{Nd}[\mathrm{T}]}$ & $\mathrm{T}_{\mathrm{DM}}$ \\
\hline 1 & 40.3 & 100.7 & 1.157 & $0.712839(14)$ & $0.709829(39)$ & 2.91 & 11.4 & 0.1549 & $0.512420(6)$ & $0.512235(6)$ & -3.28 & 1893 \\
\hline 2 & 105.0 & 380.1 & 0.7998 & $0.711321(8)$ & $0.709240(26)$ & 5.27 & 27.1 & 0.1178 & $0.512337(6)$ & $0.512196(6)$ & -4.03 & 1294 \\
\hline 3 & 150.6 & 149.3 & 2.922 & $0.716871(11)$ & $0.709268(92)$ & 4.36 & 20.5 & 0.1286 & $0.512356(6)$ & $0.512202(6)$ & -3.91 & 1424 \\
\hline 4 & 117.4 & 65.3 & 5.209 & $0.722702(9)$ & $0.709147(163)$ & 7.54 & 41.6 & 0.1096 & $0.512377(6)$ & $0.512246(6)$ & -3.06 & 1134 \\
\hline 5 & 90.8 & 199.3 & 1.318 & $0.713613(10)$ & $0.710182(42)$ & 6.79 & 35.9 & 0.1143 & $0.512394(7)$ & $0.512257(7)$ & -2.84 & 1162 \\
\hline
\end{tabular}




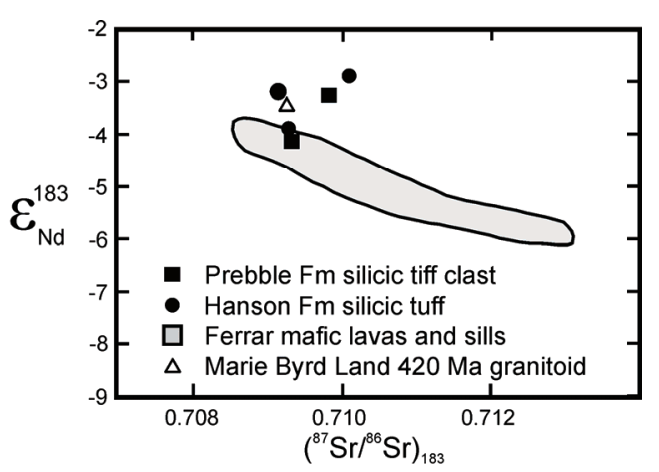

Figure 4. $\varepsilon_{\mathrm{Nd}}$ versus ${ }^{87} \mathrm{Sr} /{ }^{86} \mathrm{Sr}$ for silicic tuffs and tuff clasts, together with a Marie Byrd Land granitoid and the field for Ferrar lavas and sills.

1987). Ferrar tholeiites have similar $\mathrm{Sr}$ isotope initial ratios but somewhat lower $\mathrm{Nd}$ initial isotope ratios (respectively: $0.7085-0.7117$ and 0.51213-0.51219; Fleming et al., 1995) than the tuffs; nevertheless, the crustal contaminant contributing to the Ferrar isotope signature must have been significantly more radiogenic than the silicic tuffs and their source region. Further, the tuff $\epsilon_{\mathrm{Nd}}$ values (-2.8 to -4.0) are distinct from Ferrar rocks $\left(\epsilon_{\mathrm{Nd}}=-4.0\right.$ to -6.0 ; Fleming et al., 1995). Evolution of Ferrar Ferrar magmas occurred at their site of origin in the proto-Weddell Sea region (Elliot and Fleming, 2004, and references therein) and thus similar characteristics would not be expected. Four of the five silicic tuffs have $\mathrm{Nd}$ model ages $\left(\mathrm{T}_{\mathrm{DM}}\right.$ of 1.1-1.4 Ga) that differ from those of the underlying Ross orogen $\left(\mathrm{T}_{\mathrm{DM}}=1.6-1.9 \mathrm{Ga}\right)$, but one $\left(\mathrm{T}_{\mathrm{DM}}=1.9 \mathrm{Ga}\right)$ is similar to the adjacent Miller Range block $\left(\mathrm{T}_{\mathrm{DM}}=2.0 \mathrm{Ga}\right.$ ) (Borg et al., 1990). The silicic tuffs were not derived from the same crustal province as the contaminant for Ferrar magmas, nor by anatexis of Ross orogen crust.

Paleozoic and Mesozoic orogenic belts and magmatic arcs lie outboard of the TAM (Pankhurst et al., 1993, 1998; Mukasa and Dalziel, 2000) but evidence for Early Jurassic magmatism along the Gondwana paleo-Pacific margin is scant (Fig. 5). In the New Zealand region, parts of the Brook Street and Murihiku terranes indicate an Early Jurassic magmatic arc (Adams et al., 2002), and the Bounty Islands granite has an age of $183 \pm 9 \mathrm{Ma}$ (Adams and Campbell, 2005). The Jones Mountains granite has an age of $198 \pm 2 \mathrm{Ma}$ (Pankhurst et al., 1993), and a pluton in central Antarctic Peninsula an age of $181 \mathrm{Ma}$ (Leat et al., 1995). In the southern Antarctic Peninsula, the Brennecke and Mt. Poster formations record Early Jurassic silicic volcanism (Pankhurst et al., 2000; Riley et al., 2001). The intra-plate granitoids of the EllsworthWhitmore Mountains block (EWB) have latest Early Jurassic ages of ca. $175 \mathrm{Ma}$ (Storey et al., 1988).

Of the Lower Jurassic magmatic rocks, none has similar $\mathrm{Nd}$ isotope initial ratios and only the Jones Mountains granite has similar $\mathrm{Sr}$ isotope initial ratios

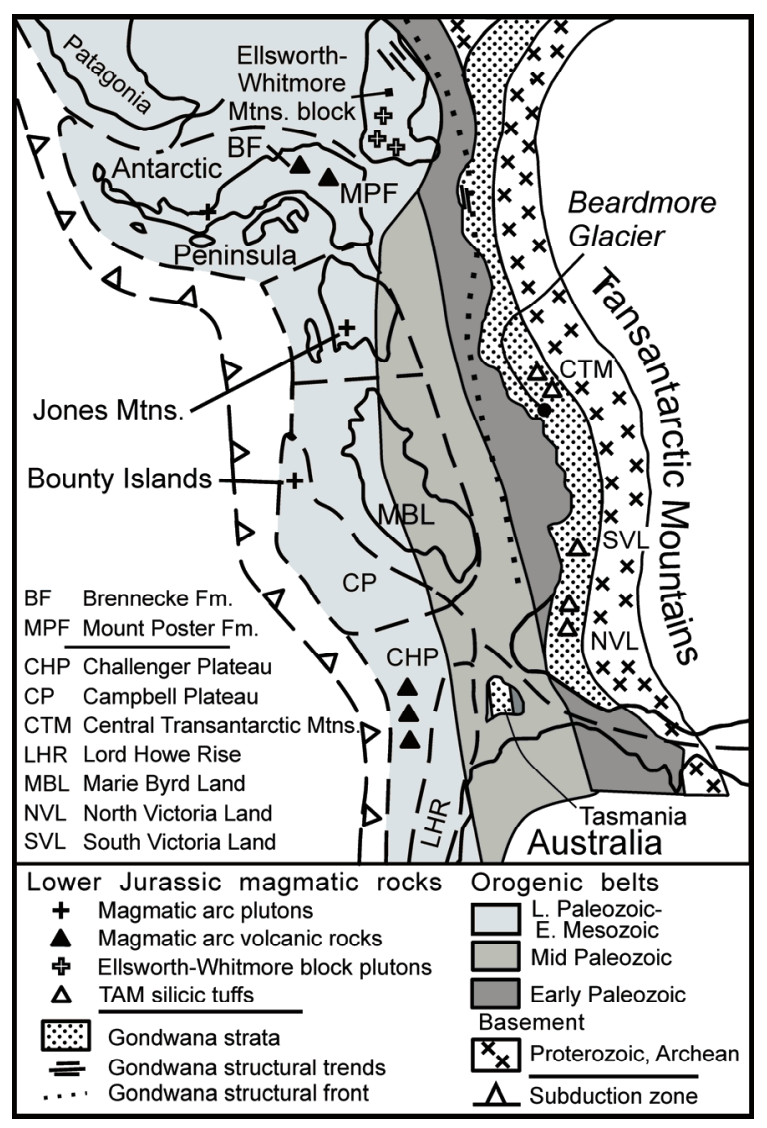

Figure 5. Gondwana reconstruction for the Early Jurassic, showing the distribution of contemporaneous magmatism and Paleozoic orogenic belts.

(Pankhurst et al., 1993). None of these magmatic centers was the source for the Hanson tuffs. Among the analyzed Paleozoic granitoids and gneisses, many having Mesoproterozoic Nd model ages (Pankhurst et al., 1998), only one, a 420 Ma granitoid, has Sr and $\mathrm{Nd}$ initial isotope ratios compatible with the Hanson tuffs.

Although the EWB is close to CTM today, in Jurassic time it was located ca. 2,000 km distant between adjacent southern Africa and Queen Maud Land. The Gondwana margin blocks were similarly displaced toward South America, and were also closer to TAM before break-up, given the extended and thinned crust of West Antarctica (Winberry and Anandakrishnan, 2004) (Fig. 5).

Silicic volcanism in the TAM is a regional phenomenon extending over $1400 \mathrm{~km}$. Although not yet well documented, the rocks in NVL and SVL containing silicic shards are clearly part of the section between Triassic siliciclastic strata and Ferrar lavas. Silicic tuffs from both Coombs Hills and the Deep Freeze Range are high-silica rhyolites (Elliot, unpublished data) and similar to the tuffs from CTM.

The tectonic setting for the Hanson Fm, inferred to have been an active rift, was initiated in early Hanson 
time, shown by arkosic sandstones in the lower member, and implies that a back-arc extensional setting formed within the previous foreland basin (see Elliot, 2000). The rift extended into NVL, controlling the long distance dispersal of Ferrar magmas (Elliot and Fleming, 2004). In terms of the plate margin, trench roll-back may have caused the extension, but magmatism along the margin did not intensify until the Middle Jurassic with major activity in the Antarctic Peninsula (Leat et al., 1995).

Silicic volcanism recorded in the lower and middle members of the Hanson Fm is inferred to reflect distal Plinian eruptions, whereas in the upper member it was proximal based on the presence of coarse-grained fallout debris. Thick tuff beds, required for the megaclasts, have not yet been recorded in any stratigraphic sequence; nevertheless the megaclasts imply a proximal source. Distal eruptions could have occurred along, or inboard of, the plate margin, yet the available geochemistry and isotope data do not show clear differences in composition between the distal and proximal volcanism.

\section{Summary}

The distribution and age of silicic volcanism in the TAM are compatible with an origin related either to Ferrar magmatism or to plate margin processes, the latter including extension in the back-arc region and both distal and proximal volcanism. Available isotopic data suggest the tuffs were derived from a crustal province with the same $\mathrm{Nd}$ model age as that of the EWB granitoids and Mount Poster Fm rocks, as well as parts of Marie Byrd Land, but not yet known from the TAM. Ferrar magmas could have caused anatectic melting of appropriate but unexposed CTM crust, in particular for the proximal tuffs, but the source for the distal rhyolitic tuffs might then have been located in West Antarctica and from as-yet-unidentified Early Jurassic magmatic centers, or from more distal centers in the TAM. In conclusion, the data constrain the source(s) to unexposed Early Jurassic magmatic centers in West Antarctica or an unexposed TAM crustal terrain that underwent Ferrar-related anatectic melting.

Acknowledgments Field work and chemical analyses were supported by NSF grant numbers OPP 95-27816 and OPP 00-87919 (DHE). We thank Jeff Linder and Fritz Hubacher for assistance in the Radiogenic Isotope Laboratory. DHE thanks Dr. C.A. Ricci and the Italian Antarctic Program for the opportunity to examine rocks in the Deep Freeze Range. We thank Sam Mukasa, Lothar Viereck-Goette and coeditor Wesley Le Masurier for careful reviews. Byrd Polar Research Center contribution No. C-1359.

\section{References}

Adams, C.J., and H. Campbell (2005), Paleozoic and Mesozoic terranes of easternmost Gondwanaland at the Pacific Ocean margin of Zelandia, Gondwana 12, Abstracts, edited by R.J. Pankhurst, and G.D. Veiga, p. 34, Academia Nacional de Ciencias, Argentina.

Adams, C.J., M.E. Barley, R. Maas, and M.G. Doyle (2002), Provenance of Permian-Triassic volcaniclastic sedimentary terranes in New Zealand: evidence from their radiogenic isotope characteristics and detrital mineral age patterns, N.Z. J. Geol. Geophys., 45, 221-242.

Borg, S.G., DePaolo, D.J., and B.M. Smith (1990), Isotopic structure and tectonics of the central Tansantarctic Mountains, J. Geophys. Res., 95, 6647-6667.

Elliot, D.H. (2000), Stratigraphy of Jurassic pyroclastic rocks in the Transantarctic Mountains, Antarctica, J. Afr. Earth Sci., 31, 77-89.

Elliot, D.H., and T.H. Fleming (2004), Occurrence and dispersal of magmas in the Jurassic Ferrar large Igneous Province, Antarctica, Gond. Res., 7, 223-237.

Elliot, D.H., Fortner, E.H., and C.B. Grimes (2006), Mawson breccias intrude Beacon strata at Allan and Coombs Hills, south Victoria Land: regional implications, Antarctica: Contributions to global earth sciences, edited by D.K. Futterer, D. Damaske, G. Kleinschmidt, H. Miller, and F. Tessensohn, pp. 289-296, SpringerVerlag, Berlin.

Encarnación, J., T.H. Fleming, D.H. Elliot, and J.V. Eales (1996), Synchronous emplacement of Ferrar and Karoo dolerites and the early breakup of Gondwana., Geology, 24, 535-538.

Faure, G., and R.L. Hill (1973), Age of the Falla Formation (Triassic), Queen Alexandra Range, Ant. J. U.S., 8(5), 264-266.

Fleming, T.H., K.A. Foland, and D.H. Elliot (1995), Isotopic and chemical constraints on the crustal evolution and source signature of Ferrar magmas, North Victoria Land, Antarctica, Contrib. Mineral. Petrol., 121, 217-236.

Foland, K.A, and J.C. Allen (1991), Magma sources for Mesozoic anorogenic granites of the Whiter Mountain magma series, New England, USA, Contrib. Mineral. Petrol., 109, 195-211.

Hammer, W.R., and W.J. Hickerson (1994), A Crested Theropod Dinosaur from Antarctica, Science, 264, 828-830.

Kalamarides, R.I., J.H. Berg, and R.A. Hank (1987), Lateral isotopic discontinuity in the lower crust: an example from Antarctica, Science, 237, 1192-1195.

Leat, P.T., J.H. Scarrow, and I.L. Millar (1995), On the Antarctic Peninsula Batholith, Geol. Mag., 132, 399-412.

Mukasa, S.B., and I.W.D. Dalziel (2000), Marie Byrd Land, West Antarctica: Evolution of Gondwana's Pacific margin constrained by zircon U-Pb geochronology and feldspar common- $\mathrm{Pb}$ isotopic compositions, Geol. Soc. Amer. Bull., 112, 611-627.

Musumeci, G., P.C. Pertusati, C. Ribecai, and M. Meccheri (2006), Early Jurassic fossiliferous black shales in the Exposure Hill formation, Ferrar Group of northern Victoria Land, Antarctica, Terra Ant. Rept., 12, 91-98.

Pankhurst, R.J., I.L. Millar I.L., A.M. Grunow, and B.C. Storey (1993), The pre-Cenozoic magmatic history of the Thurston Island crustal block, West Antarctica, J. Geophys. Res., 98, 11,835-11,850.

Pankhurst, R.J., S.D. Weaver, J.D. Bradshaw, B.C. Storey, and T.R. Ireland (1998), Geochronology and geochemistry of pre-Jurassic superterranes in Marie Byrd Land, Antarctic, J. Geophys. Res., 103, 2,529-2,547.

Pankhurst, R.J., T.R. Riley, C.M. Fanning, and S.P. Kelley (2000), Episodic silicic volcanism in Patagonia and the Antarctic Peninsula: Chronology of magmatism associated with the break-up of Gondwana, J. Petrol., 41, 605-625.

Peate D. (1997), The Paraná-Etendeka Province, Large Igneous Provinces: Continental, Oceanic, and Planetary Flood Volcanism, Geophys. Mono. number 100, edited by J.J. Mahoney and M.F. Coffin, pp. 217-245, Amer. Geophys. Union, Washington D.C.

Pertusati, P.C., C. Ribecai, R. Carosi, and M. Meccheri (2006), Early Jurassic age for youngest Beacon supergroup strata based on palynomorphs from Section Peak, northern Victoria land, Antarctica. Terra Ant. Rept. 12, 99-104.

Riley, T.R., P.T. Leat, R.J. Pankhurst, and C. Harris (2001), Origins of large volume rhyolitic volcansim in the Antarctic Peninsula and Patagonia by crustal melting, J. Petrol., 42, 1043-1065.

Storey, B.C., M.J. Hole, R.J. Pankhurst, I.L. Millar, and W.R. Vennum (1988), Middle Jurassic within-plate granites in West Antarctica and their bearing on the break-up of Gondwanaland, J. Geol. Soc. London, 145, 999-1007.

Winberry, J.P., and S. Anandakrishnan ( 2004), The crustal structure of the West Antarctic rift system and Marie Byrd Land hotspot, Geology, 32, 977-980. 